\title{
FORMULASI EKSTRAK ETANOL DAUN ALPUKAT (Persea americana Mill) DAN DAUN SIRIH (Piper betle) SEBAGAI INSEKTISIDA BERBENTUK MAT ELEKTRIK TERHADAP NYAMUK AEDES AEGYPTI
}

\author{
Arifuddin Yunus ${ }^{1}$, Dwi Fitrah Wahyuni², An Nisaa Nurzak ${ }^{3}$ \\ 1,2,3 STIKes Salewangang Maros \\ Email Korespondensi : dwifitrah2208@gmail.com
}

\begin{abstract}
ABSTRAK
Epidemologi dan luas daerah penyebaran penyakit DBD semakin bertambah seiring dengan meningkatnya mobilitas dan kepadatan penduduk. Salah satu upaya yang dilakukan dalam memberantas vektor nyamuk dengan menggunakan insektisida. Penelitian ini bertujuan untuk menguji efektivitas kombinasi ekstrak etanol daun alpukat (Persea americana) dan daun sirih (Piper betle) terhadap kematian nyamuk Aedes aegypti. Rancangan Penelitian ini eksperimental dengan post test only control group design. Mat elektrik yang telah di rendam dengan kombinasi ekstrak etanol daun alpukat (Persea americana) dan ekstrak etanol daun sirih (Piper betle) di bagi menjadi 4 kelompok konsentrasi yaitu kontrol positif, kontrol negatif, dan kombinasi ekstrak dengan konsentrasi 1\%, 3\% dan 5\%. Selanjutnya diuji dengan 10 ekor nyamuk Aedes aegypti ditiap perlakuan. Hasil penelitian menunjukkan pada konsentrasi 5\% mampu membunuh nyamuk Aedes aegypti sebanyak 10 ekor hanya dalam waktu 5 menit dibanding dengan konsentrasi $1 \%$ dan 3\%. Dari penelitian ini dapat disimpulkan bahwa semakin besar konsentrasi ekstrak yang digunakan maka semakin cepat durasi waktu untuk membunuh nyamuk Aedes aegypti.
\end{abstract}

Kata kunci: Demam Berdarah, Daun Alpukat, Daun Sirih, Insektisida, Aedes aegypti 


\title{
FORMULATION OF AVOCADO (Persea americana Mill) AND PIPER BETLE (Piper betle) ETHANOL EXTRACT AS ELECTRIC MAT INSECTICIDES AGAINST AEDES AEGYPTI MOSQUITO
}

\begin{abstract}
The epidemiology and area of the spread of DHF is increasing along with the increasing mobility and population density. One of the efforts made in eradicating mosquito vectors is by using insecticides. This study aimed to examine the effectiveness of the combination of avocado (Persea americana) and betel leaf (Piper betle) ethanol extracts against the death of Aedes aegypti mosquitoes. This study aimed to examine the effectiveness of the combination of avocado (Persea americana) and betel leaf (Piper betle) ethanol extracts against the death of Aedes aegypti mosquitoes. This research design is experimental with post test only control group design. The electric mat that had been soaked with a combination of ethanolic extract of avocado (Persea americana) and ethanolic extract of betel leaf (Piper betle) was divided into 4 concentration groups, namely positive control, negative control, and a combination of extracts with concentrations of $1 \%, 3 \%$ and $5 \%$. Then tested with 10 Aedes aegypti mosquitoes in each treatment. Then tested with 10 Aedes aegypti mosquitoes in each treatment. The results showed that at a concentration of 5\% it was able to kill 10 Aedes aegypti mosquitoes in just 5 minutes compared to concentrations of $1 \%$ and 3\%. From this study it can be concluded that the greater the concentration of extract used, the faster the duration of time to kill the Aedes aegypti mosquito.
\end{abstract}

Keywords: Dengue Fever, Avocado Leaf, Betel Leaf, Repellant, Aedes aegypti

\section{PENDAHULUAN}

Penyakit DBD di Indonesia penyebaran penyakit ke wilayah lain. masih merupakan masalah kesehatan Demam Berdarah Dengue (DBD) karena masih banyak daerah yang merupakan penyakit infeksi yang endemik. Daerah endemik DBD pada umumnya merupakan sumber disebabkan oleh virus dengue, yang biasanya ditemukan di daerah tropis. 
Infeksi virus dengue dapat menyebabkan kematian dan kesakitan yang tinggi di seluruh dunia. Dinas Kesehatan Kota Makassar selama 3 tahun terakhir yakni 2016 - 2018 menunjukkan jumlah kasus DBD per kecamatan di Kota Maksassar secara berturut-turut yaitu Kecamatan Panakukang sebanyak 81 kasus, Kecamatan Tamalate sebanyak 78 kasus, Kecamatan Manggala sebanyak 72 kasus, Kecamatan Rappocinik sebanyak 71 kasus, dan Kecamatan Biringkanaya sebanyak 69 Kasus (Ibrahim \& Manyullei, 2019).

Upaya pencegahan dan pemberantasan penyakit DBD saat ini adalah secara mekanis, fisik, kimiawi atau secara biologi. Salah satu upaya yang dilakukan dalam memberantas vektor nyamuk dengan menggunakan insektisida. Penggunaan insektisida sintetis ini pada kurun waktu 40 tahun terakhir semakin meningkat baik dari kualitasnya maupun kuantitasnya. Hal ini disebabkan insektisida sintetis tersebut mudah digunakan, lebih efektif, dan dari segi ekonomi lebih menguntungkan (Sukowati, 2010). Mengingat penggunaan insektisida sintetik menimbulkan banyak efek negatif karena mengandung hidrokarbon terhalogenasi yang diketahui mempunyai waktu paruh terurai yang relatif panjang dan dikhawatirkan memiliki sifat racun (Aini et al., 2017).

Untuk mengurangi efek yang berbahaya dari penggunaan insektisida maka perlu dilakukan upaya pengendalian yang lebih aman dan lebih murah dengan menggunakan bahan alami seperti penggunaan ekstrak beberapa jenis tumbuh-tumbuhan yang dapat bersifat sebagai larvasida dan insektisida karena mengandung senyawa seperti alkaloid, flavonoid, tanin, kuinon, saponin, dan triterpenoid seperti pada daun sirih (Piper betle) dan daun alpukat (Persea americana) (Sitorus, 2019).

Daun sirih (Piper betle) mengandung senyawa tanin sebagai senyawa yang berpotensi menjadi racun bagi tubuh serangga. Tanin berfungsi sebagai substansi perlindungan dalam jaringan maupun luar jaringan. Tanin juga berfungsi sebagai zat astringent yang dapat menyusutkan jaringan dan menutup struktur protein pada kulit dan mukosa. Tanin umumnya tahan terhadap fermentasi dan dapat menurunkan kemampuan binatang untuk mengkonsumsi tanaman (Yennie \& Elystia, 2013).

https://doi.org/10.33759/jrki.v4i1.219 
Ekstrak daun alpukat berpotensi sebagai insektisida, senyawa kimia yang terkandung dari daun alpukat (Persea americana) adalah antara lain alkaloid, saponin, tanin dan flavonoid. Alkaloid dalam daun dan biji dapat mendegradasi dinding sel lalu masuk ke dalam untuk merusak sel dan mengganggu sistem kerja syaraf pada nyamuk. Saponin bersifat sebagai antimikroba dan bersifat sangat toksik bagi serangga, mengandung bagian yang bersifat hormonal dari golongan steroid yang dapat berpengaruh dalam pertumbuhan nyamuk, saponin juga berperan sebagai racun perut yang dapat menurunkan aktivitas enzim pencernaan dan penyerapan makanan dan menghambat kerja enzim kolinesterase pada nyamuk (Dwina, 2014).

Pada penelitian ini diharapkan dapat menjadi salah satu alternatif yang aman digunakan oleh masyarakat dalam memanfaatkan bahan alam sebagai reppelant pada nyamuk Aedes aegepty.

\section{METODE PENELITIAN}

MATERIAL

Bahan - bahan yang digunakan dalam penelitian ini adalah daun alpukat (Persea americana) dan daun sirih (Piper betle) yang diperolah dari kabupaten maros, Sulawesi selatan. Silica gel ${ }^{\circledR}$ merck, etanol $96 \% \AA$ merck, etanol $70 \% \AA$ merck, Baygon $\AA$ mat elektrik, kertas karton putih.

Alat yang digunakan adalah rotary evaporator, batang pengaduk, beaker glass, botol maserasi berwarna gelap, cawan penguap, gelas ukur, kandang nyamuk, kertas perkamen, kertas saring, mortar dan stamper, penjepit kayu, pipet tetes, tabung reaksi, rak tabung, timbangan analitik, waterbath (penangas air), star home ${ }^{\circledR}$ mosquito trap.

1) Rancangan Penelitian

Penelitian ini merupakan jenis penelitian eksperimen dengan pendekatan The Post Test Only Control Group Design yang menggunakan nyamuk. Populasi dalam penelitian adalah nyamuk Aedes aegypti, dimana setiap kotak berisi 10 nyamuk dengan 2 kali replikasi. Teknik pengambilan nyamuk dilakukan secara acak (random sampling) dengan melakukan pengujian terhadap pengaruh insektisida nyamuk elektrik ekstrak etanol kombinasi daun alpukat (Persea americana) dan daun sirih (Piper betle) berbagai konsentrasi yang dibandingkan dengan anti https://doi.org/10.33759/jrki.v4i1.219 
nyamuk konvensional (Baygon ${ }^{\circledR}$ met elektrik) sebagai kontrol positif dan met tanpa ekstrak sebagai kontrol negatif.

2) Ekstraksi

Ekstraksi sampel dilakukan dengan metode maserasi dimana sampel direndam menggunakan pelarut etanol. Sampel daun alpukat (Persea americana) dan daun sirih (Piper betle) yang telah kering diserbukkan dan diekstraksi dengan menggunakan metode maserasi. Sampel dimasukkan ke dalam wadah maserasi. Wadah maserasi ditutup dan disimpan selama $1 \mathrm{x}$ 24 jam di tempat yang terlindung dari sinar matahari langsung sambil sesekali diaduk. Selanjutnya disaring, dipisahkan antara ampas dan filtrat. Filtrat etanol yang diperoleh kemudian dikumpulkan dan diuapkan cairan penyarinya dengan rotary evaporator sampai diperoleh ekstrak etanol kental

3) Persiapan Sampel Uji Nyamuk Aedes aegypti.

Dalam penelitian ini, digunakan telur nyamuk sebanyak 150 butir. Telur nyamuk diperoleh dari hasil penangkaran nyamuk dewasa yang ditangkap menggunakan alat penangkap nyamuk, kemudian dikembangbiakkan hingga menghasilkan telur nyamuk pilihan, kemudian dibagi menjadi 5 kelompok yang terdiri atas 30 butir telur nyamuk. Kriteria inklusi sampel yang digunakan pasca menetas menjadi nyamuk yang dipilih adalah nyamuk dewasa yang bertahan selama 4 hari, sehingga di dapatkan sampel 20 ekor nyamuk setiap kelompok. Setiap kelompok diberikan met elektrik yang berisi ekstrak etanol kombinasi daun alpukat (Persea americana) dan daun sirih (Piper betle) pada konsentasi 1\%, 3\%, $5 \%$, kontrol positif dan kontrol negatif. Kemudian dilakukan pengamatan untuk selama 60 menit untuk melihat jumlah nyamuk yang terbang menjauhi sumber mat/mati.

\section{HASIL DAN PEMBAHASAN}

Pengujian Anti Nyamuk Ekstrak

Etanol kombinasi daun alpukat 
(Persea americana) dan daun sirih

\section{(Piper betle)}

Hasil pengujian anti nyamuk dapat dilihat pada Tabel 1 dari rata-rata kematian nyamuk dan perbandingan efektivitas anti nyamuk elektrik komersial dengan ekstrak etanol kombinasi daun alpukat (Persea americana) dan daun sirih (Piper betle) pada konsentrasi $1 \%, 3 \%$ dan $5 \%$, dengan dua kali pengulangan selama 1 jam.

Tabel 1. Rata-rata kematian nyamuk Aedes aegypti selama 1 jam

\begin{tabular}{ccccccc}
\hline $\begin{array}{c}\text { Konsentrasi } \\
\text { kombinasi } \\
\text { ekstrak }\end{array}$ & $\begin{array}{c}\text { Replikasi } \\
\text { ke- }\end{array}$ & \multicolumn{5}{c}{ Kematian nyamuk Aedes aegypti (menit ke-) } \\
\cline { 3 - 6 } $1 \%$ & I & 0 & 10 & 15 & 30 & 60 \\
\hline \multirow{3}{*}{$1 \%$} & II & 0 & 0 & 2 & 2 & 6 \\
$3 \%$ & R & 0 & 0 & 2 & 3 & 5 \\
& I & 0 & 2 & 8 & 0 & 0 \\
$5 \%$ & II & 2 & 2 & 6 & 0 & 0 \\
& R & 1 & 2 & 7 & 0 & 0 \\
& I & 10 & 0 & 0 & 0 & 0 \\
kontrol $(+)$ & II & 10 & 0 & 0 & 0 & 0 \\
& R & 10 & 0 & 0 & 0 & 0 \\
& I & 10 & 0 & 0 & 0 & 0 \\
Kontrol (-) & II & 10 & 0 & 0 & 0 & 0 \\
& R & 10 & 0 & 0 & 0 & 0 \\
& I & 0 & 0 & 0 & 0 & 0 \\
& II & 0 & 0 & 0 & 0 & 0 \\
& R & 0 & 0 & 0 & 0 & 0 \\
\hline
\end{tabular}

Keterangan:

Kontrol $(+) \quad=$ Met elektrik umum $\left(\right.$ Baygon ${ }^{\circledR}$ Elektrik)

Kontrol (-) = Met tanpa ekstrak

$\mathrm{R}=$ Rata-rata jumlah nyamuk yang mati

Hasil pada Tabel 1 menunjukkan bahwa kematian tertinggi nyamuk Aedes aegypti dalam rata-rata jumlah kematian setiap konsentrasi berturut-turut adalah konsentrasi $1 \%$ mencapai kematian 5 nyamuk di menit ke 60 ; konsentrasi $3 \%$ mencapai kematian 7 nyamuk di menit ke 15 ; konsentrasi $5 \%$ mencapai kematian 10 nyamuk di menit 5. Kontrol positif menunjukkan kematian nyamuk Aedes aegypti pada menit ke-5. Berdasarkan pengamatan, tampak 
terjadinya perubahan pergerakan nyamuk sebelum dan sesudah dinyalakan anti nyamuk mat elektrik. Nyamuk Aedes aegypti dari yang bergerak sangat aktif berusaha keluar (karena aroma yang dikeluarkan mat) sampai pada akhirnya menjadi lamban dan lemas, dan kemudian lumpuh dan mati. Dapat dilihat pada konsentrasi 5\% rata-rat jumlah yang mati 10 ekor. Penelitian tersebut serupa dengan penelitian yang dilakukan oleh dwina tentang daya tolak reppelant berbentuk lotion dengan ekstrak daun alpukat, dikatakan bahwa kematian nyamu ada pada ekstrak alpukat dengan konsetrasi 5\% (Dwina,2014). Salah satu senyawa yang diduga mempengaruhi perubahan sistem saraf serangga adalah flavonoid. Senyawa flavonoid bekerja sebagai racun inhalasi dengan masuk ke dalam mulut serangga melalui saluran pencernaan berupa spirakel yang terdapat di permukaan tubuh yang kemudian akan menimbulkan kelayuan pada saraf dan kerusakan pada spirakel, hal tersebut mengakibatkan serangga tidak bisa bernafas dan mati (Sitorus, 2109). Penelitian lain juga dilakukan oleh fuad terkait dengan pengujian efikasi ekstrak daun sereh terhadap sebagai larvasida terhada larva Aedes aegypti bahwa semakin besar konsentrasi ekstrak yang diberikan maka semakin besar jumlah kematian larva yang diperoleh (Fuad,2020). Senyawa yang berperan sebagai insektisida adalah alkaloid dan saponin. Alkaloid dalam daun dan biji dapat mendegradasi dinding sel lalu masuk ke dalam untuk merusak sel dan mengganggu sistem kerja syaraf pada nyamuk (Astriani \& Widawati,2016). Saponin juga berperan sebagai racun perut yang dapat menurunkan aktivitas enzim pencernaan dan penyerapan makanan dan menghambat kerja enzim kolinesterase pada nyamuk (Dwina,2014). Selain itu Saponin bersifat sangat toksik bagi serangga karena mengandung bagian yang bersifat hormonal dari golongan steroid yang dapat berpengaruh dalam pertumbuhan nyamuk (Sukowati,2010). Hal tersebut menunjukkan bahwa ekstrak etanol kombinasi daun alpukat (Persea americana) dan daun sirih (Piper betle) berpotensi sebagai insektisida.

\section{KESIMPULAN}

Kesimpulan dari penelitian ini adalah ekstrak etanol kombinasi daun alpukat (Persea americana) dan daun sirih (Piper betle) pada konsentrasi 1\% dan https://doi.org/10.33759/jrki.v4i1.219 
3\% memiliki efektivitas yang kurang optimal dibandingkan dengan kontrol positif, sedangkan pada konsentrasi 5\% ektrak etanol kombinasi daun alpukat (Persea americana) dan daun sirih (Piper betle) berpotensi sebagai insektisida nyamuk alami.

\section{UCAPAN TERIMAKASIH}

Pada kesempatan ini, peneliti ingin mengucapkan terima kasih kepada berbagai pihak yang telah membantu terwujudnya penelitian ini :

1. Ketua Sekolah Tinggi Ilmu Kesehatan Salewangang Maros

2. Ketua Lembaga Penelitian dan Pengabdian Sekolah Tinggi Ilmu Kesehatan

\section{DAFTAR PUSTAKA}

Aini, R., Widiastuti, R., \& Nadhifa, N.

A. (2016). uji efektifitas formula spray dari minyak atsiri herba kemangi (ocimum sanctum 1) sebagai repellent nyamuk aedes aegypti. jurnal ilmiah manuntung, 2(2), 189-197.

Ardiyan, A. (1992). Tinjauan Pustaka Penggunaan Pestisida bagi Berbagai Jenis Tanaman, 7-29.
Retrieved from

http://eprints.undip.ac.id/43729/3/p

df

Astriani, Y., \& Widawati, M. (2016).

Potensi Tanaman Di Indonesia

Sebagai Larvasida Alami Untuk Aedes Aegypti Spirakel, Doi: 10.22435/Spirakel.V8i2.6166.37-

46 , (Desember).

\section{Https://Doi.Org/10.22435/}

Spirakel. V8i2.6166.37-46

Budiman, \& Rahmawati. (2015). Perbandingan Efektivitas Ekstrak Zodia (Evodia sauveolens) dan Serai ( Cymbopogan citratus ) Sebagai Repellent ( Penolak ) Nyamuk. Higiene.

Dwina, Rizki Anindhita, Budiyono. 2014. "Daya Tolak Repellent Bentuk Lotion dengan Ekstrak Daun Alpukat”. Jurnal Kesehatan Masyarakat. 3(5) $: 703$

Fuad,2020.Efektivitas ekstrak etanol daun sirih sebagai larvasida terhadap larva aedes aegypti kecamatan Denpasar selatan, Bali. Jurnal Medika Undayana. Vol 9 no 9. 
Handayani, r. (2017). faktor-faktor aini, r., widiastuti, r., \& nadhifa, n. a. (2017). uji efektifitas formula spray dari minyak atsiri herba kemangi (ocimum sanctum 1 ) sebagai repellent nyamuk aedes aegypti. jurnal ilmiah manuntung, 2(2), 189. https://doi.org/10.51352/jim.v2i2.6 6

Ibrahim, E., \& Manyullei, S. (2019). studi keberadaan larva aedes aegypti sebelum dan sesudah intervensi psn dbd di kelurahan pandang kecamatan panakukang kota makassar. 2, 12.

Kementrian Kesehatan Republik Indonesia. (2018), laporan nasional riset kesehatan dasar 2018.pdf.

Ojewumi, M. E., Adedokun, S. O., Omodara, O. J., Oyeniyi, E. A., Taiwo, O. S., \& Ojewumi, E. O. (2017). Phytochemical and Antimicrobial Activities of the Leaf Oil Extract of Mentha Spicata and its Efficacy in Repelling Mosquito, 6(4), 17-27.

Ranasinghe, m. s. n., arambewelaand, 1., \& samarasinghe, s. (2016). development of herbal mosquito repellent formulations.

international journal of pharmaceutical sciences and research, 7(may). https://doi.org/10.13140/rg.2.2.178 57.25443

Sitorus, H., \& Marini. (2019). Beberapa tanaman yang berpotensi sebagai repelen di indonesia. SPIRAKEL, DOI:Https://Doi.Org/10.22435/Spi rakel.V11i1.1585, 11(1), 24-33.

Sukohar. (2014). Demam Berdarah Dengue (DBD). Medula, Fakultas Kedokteran Universitas Lampung, $2,1-15$.

Sukowati. (2010). Masalah Vektor DBD dan Pengendaliannya. Buletin Jendela Epidemiologi.

World Health Organization. (2009). dengue guidelines for diagnosis, treatment, prevention and control (New Edition, 2019).

Yennie, E., \& Elystia, S. (2013). pembuatan pestisida organik menggunakan metode ekstraksi dari sampah daun pepaya dan umbi bawang putih. jurnal dampak, 10(1),

46. 
https://doi.org/10.25077/dampak.1

$0.1 .46-59.2013$

Zen, S., \& Noor, R. (2016). inventarisasi tanaman yang berpotensi sebagai bioinsektisida nyamuk aedes aegyptii di kota metro provinsi lampung. bioedukasi, jurnal pendidikan biologi. universitas muhammadiyah metro, 7(2). 